\title{
Development of Bedulu Village Towards Future Tourism
}

\author{
Ni Komang Nariani \\ International Bali Institute of Tourism, Bali, Indonesia \\ I Komang Gde Bendesa, Made Budiarsa \\ Udayana University, Bali, Indonesia
}

\begin{abstract}
Tourism is one of the largest industries in the world and a promising sector to boost a country's growth. Bedulu Village in Gianyar Regency, Bali, is a village with high tourism potential. The village has beautiful natural scenery and archaeological heritage sites, which enable tourists to enjoy culture, nature, pilgrimage, and educational tourism. Although some efforts have been made by the locals to improve the quality of tourism, the management of tourism in Bedulu Village is still handled sketchily using a simple system, in addition to a lack of proper human resources and infrastructure. Therefore, Bedulu Village still requires further development for potential tourism attraction in order to become quality tourist destination in the future. The purpose of this study was to analyze the current situation of tourism in Bedulu and determine the necessary development needed for future tourism in Bedulu Village. The data collected from the object of research were analyzed using descriptive-qualitative analytical method. The results from this study are: While Bedulu Village has been adequately prepared in terms of tourist attractions and tourist accommodation, it is still in need of further development in areas, such as infrastructure, marketing, and the empowerment of local community. This will allow the village to stay competitive in the face of mass tourism of nearby places, like Ubud and lead to community's welfare, which in turn will secure future tourism of Bedulu Village.
\end{abstract}

Keywords: development, community-based tourism, future, empowerment

\section{Introduction}

Tourism is one of the largest industries in the world and a promising sector to boost a country's growth. Growth in this sector could help unlock private investment, create jobs, boost exports, and guide infrastructure investments. According to the World Travel and Tourism Council, every \$1 million in travel and tourism spending supports around 200 jobs and \$1.7 million in GDP for Indonesia (World Bank, 2016). Indonesian government hopes that tourism can boost foreign exchange earnings by increasing the number of visits to Indonesia. While the number of visits to Indonesia in 2014 reached 9.7 million tourists, the government expects the number of visits to reach 20 million tourists including from Association of Southeast Asian Nations (ASEAN) countries by 2019. However, the quantity and quality of travelers should be equally prioritized, in order to reach quality tourism. In order to meet this expectation, the government should strive to set up better facilities,

Ni Komang Nariani, SE., MM., International Bali Institute of Tourism, Bali, Indonesia.

I Komang Gde Bendesa, prof., Dr., M.A.D.E., Faculty of Tourism, Udayana University, Bali, Indonesia.

Made Budiarsa, prof., Dr., M.A., Faculty of Tourism, Udayana University, Bali, Indonesia.

Correspondence concerning this article should be addressed to Ni Komang Nariani, International Bali Institute of Tourism, Jl. Tari Kecak no. 12, Gatot Subroto Timur, Denpasar, Bali 80239, Indonesia. Email: nk_nariani@ yahoo.com. 
infrastructure, and human resources capable of providing satisfactory services including a new tourist destination.

Bali is a small island and province of Indonesia located east of Java Island. The natural scenery, art, and culture of Bali captivate millions of tourist, making Bali a very popular tourist destination for both domestic and foreign tourist. Although there has been a period of slump on tourist visits in early 2000s, tourism in Bali has since begun to recover. According to Bali Government Tourism Office (Disparda Bali, 2017), the number of tourist visits is gradually increasing since 2008, with a total of $23 \%$ growth in foreign tourist arrival in 2016. However, this number does not reflect equal visits in all areas of Bali. Most tourism activities are concentrated on southern Bali. This leads to uneven development on other areas, especially rural ones.

The Gianyar Regency as part of Bali is renowned as a city of art and culture with abundant beautiful natural scenery. Tourism in Gianyar in particular is based on strong local customs and cultures. There are many rural areas and villages in Gianyar which considered as "hidden gem" for tourist. These places often have interesting sites and traditions, thus have significant potential to become popular tourist destination, given the right development. Bedulu Village in Gianyar is a village with high tourism potential. The village have beautiful natural scenery and archaeological heritage sites, which enables tourists to enjoy culture, nature, pilgrimage, and educational tourism. Although some efforts have been made by the locals to improve the quality of tourism, the management of tourism in Bedulu Village is still handled sketchily using a simple system, in addition to a lack of proper human resources and infrastructure. As tourism in Bedulu is still considered as alternative tourism, if the situation is left as is, it will not be able to compete with another destination that promotes mass tourism, such as Ubud. Therefore, Bedulu Village still requires further development for potential tourism attraction in order to become quality tourist destination in the future. The research was conducted to analyze the current situation of tourism in Bedulu and determine the necessary development needed for future tourism in Bedulu Village.

\section{Literature Review}

Tourism village is a formed of cultural heritage development through tourism. Besides exploring the culture and nature of destinations, it is also an attempt to sustain the cultural heritage. Ardika (2011) defined tourism village, as a journey in order to enjoy the atmosphere of rural life and gain the mutual respect and cultures, values, traditions, and natural environment, results in a two-way learning process between tourist and community, and improves the welfare of rural communities. Within cultural tourism development in tourism village, there will be a commodification culture from its originality. It is the management effort or a way to interpret the cultural message for tourist. Nevertheless, the core cultural of the origin destination may remain authentic. There are three components in cultural tourism: travel, the tourist, and the sites (Tighe, 1991, as cited in Christou, 2005; Sigala \& Leslie, 2005, p. 6).

Ardika (2011) stated that Indonesian tourism norms are divided into three aspects: community-based tourism, culture, and sustainable development. Tourism village is one of the tangible manifestations implementations in community-based tourism concept. Tourism village has a clear goal and objective for tourism development; it is beneficial to the community because it is managed by their own people and for their people. Therefore, people in community must be active, creative, and pro-active. In the community-based tourism theory, tourism village is described as the implementation of eco tourism which requires the participation of local communities. Their participation needed at the form of process, so that they can improve their own quality of life and contribute in destination development. 
The research by Putra (2009) about "The Development of Tourist Attraction based on Tri Hita Karana in Gianyar District" stated that the development which is a form of local wisdom has experienced some obstacles, such as the lack of qualified Human Resources (HR) and local tour guides, management, tourism facilities, roads, and promotions. This finding provides some insights that these obstacles must be overcome in order to further develop the area, thus the empowerment of local community is necessary to achieve that, in addition with external contribution, such as government funding to help with infrastructure.

\section{Methodology}

The research was conducted in Bedulu Village on August 2016 in the form of field studies. Bedulu Village is a village located in Blahbatuh, Gianyar, consisting of five banjar (hamlets): Banjar Margabingung, Banjar Tengah, Banjar Batulumbang, Banjar Lebah, and Banjar Goa. The scope of this study discusses the current condition and development needed in Bedulu Village. The objects were examined using the concept of 4A: attractions, amenities, accessibilities, and ancillary services in the village of Bedulu. The data collected from the object of research were then analyzed using descriptive-qualitative analytical method. The method of data collection can be detailed as follows:

1. Observation method is used by observing the activities of travelers, locals' livelihood, and cultural and natural attractions of Bedulu Village. The observation is assisted by documentation, such as photos.

2. Interviews were conducted to obtain information related to the issues discussed and assisted by taking notes of the conversation. The interviewees are foundation manager and village headmen.

3. Documentation studies from written documents, such as the history and profiles of Bedulu Village, as well as list of detailed attractions and amenities; in addition the form of pictures, such as photos of tourist attractions, village activities, and map of Bedulu Village.

\section{Results}

\section{Bedulu Village Profile}

Bedulu Village is a village that full of cultural nuances that presents a beautiful panorama and tourism offerings which focussed on the clump of archeology. It is one of nine villages in Blahbatuh sub-distric, Gianyar Regency. It consist of 11 banjar in the village, they are: Banjar Marga Bingung, Tengah, Goa, Batu Lumbang, Lebah, Pekandelan, Taman, Mas, Wanayu, Tegallinggah, and Marga Sangkala. The name of the village is derived from "bedaulu", which means upstream. The majority of the population makes their living from agriculture, specifically rice. Bedulu was once the capital of the old Balinese Kingdom Pejeng, which was the last kingdom in Bali that surrendered to the Majapahit Empire from Java, invaders of Bali in 1343. Bedulu lies within proximity to Ubud. Bedulu is a quiet and traditional Balinese village faraway from Ubud's mass tourism. Located on the banks of the Petanu River, the village achieved fame because of the nearby 11th century Elephant Cave, also known as Goa Gajah. The surrounding area boasts interesting and ancient wonders including Gunung Kawi and the Yeh Pulu carvings. In the 1930s, the modern form of the kecak dance (monkey dance) was created here. Bedulu's Museum Gedong Arca houses archeological items which reflect Balinese historical and cultural development. The village is surrounded by small canyons and paddy fields. Along the main street, there are some small warungs (food and beverage kiosks) and a night market.

Bedulu Village is an important place of Balinese history. Bedulu is an ancient village that has been inhabited since prehistoric times before Hinduism-Buddhism entered the village. They lived in a society groups in hamlets 
or groups with a simple lifestyle (custom) which has been running about 2.5 centuries. The locals had a tradition in which the dead was buried using sarcophagus system. Hindu-Buddhist influence had entered the village since 8-10 AD. As the ancient Bali society evolves, there were nine sects in Bali, namely, Sect Brahma, Pasupati, Sidantha Shiva, Vaishnava, Buddha, Brahma, Rsi, Sora, and Ganapatya. King Udayana and King Gunapriyadarmapati held a meeting to unite the sects that exist in Bali. By inviting religious figures from Bali and East Java, the meeting were held at Samuan Tiga Temple. The meeting results in an agreement for the sects to unite and support each other to run a social life with each other which was the birth of desa pekraman concept in Bali and every family to built merajan or sanggah rong tiga at their house.

As an ancient and historical place, Bedulu Village contains many sites which become interesting tourist attractions nowadays. Although not as popular as other destination, such as Ubud, as the two areas are in close proximity to each other should provide some conveniences for tourist who wanted to visit Bedulu. Bedulu Village has adequate attractions, amenities, accessibilities, and ancillary (4A) services to qualify as a tourist destination, and the village has recently promoted as tourism village. Tourism village is a form of integration between attractions, accommodations, and amenities presented in a unified structure of community life with the prevailing procedures and tradition (Nuryanti, 1993).

\section{Attractions}

There are several types of tourist attractions in Bedulu Village which can be categorized into religion, education, or nature attraction. These attractions are not necessarily standalone; however, they can overlap on each other. Some of these attractions include:

Goa Gajah. Goa Gajah, literally means "Elephant Cave". Although named by "elephant", it does not mean there is any real elephant live or ever live here. The name Goa Gajah derived from "Lawa Gajah", which is mentioned in the manuscripts that found in this site. This temple complex was built for the first time around 11th century based on epigraph found in this site. A seven-meter deep cave with a shape of T-letter is the major attraction of this Bedulu Village's local temple. The cave itself is carved in a solid stone hill of the river valley. The main figure of the carving at the cave entrance is "boma", a barong face, accompanied with big clapping fingers on its side. Nowadays, those holes are used to place offerings whenever there are ceremonies taking place. On the left end side of the cave, there is Ganesha statue, believed as "the God of knowledge". Meanwhile, on the right end side, it can be found three "linggas" that each of them dedicated to the three common God manifestations in Bali: Brahma, Wisnu, and Siwa.

Samuan Tiga Temple. Samuan Tiga Temple was built in 10th century in the reign of King Chandrasangka Warmadewa. This sacred temple was the royal temple of ancient Warmadewa dynasty. As suggested by its name, Balineses believe that Pura Samuan Tiga is a venue for the great meeting of the gods, deities, and saints-the word "samuan" means "meeting" and "tiga" means "three". The temple located about 400 meters from Goa Gajah.

Gedong Arca Purbakala. The Gedong Arca Purbakala Archaeological Museum is located close to Bedulu, on the road to Pejeng. It contains a unique collection of tufa sarcophagi of varying size dating back to $300 \mathrm{BC}$. The 53 sarcophagi were found in the early 70s on 37 different sites on Bali and brought together here. Some of them are damaged which was thought to be the work of tomb-robbers or careless excavators.

Yeh Pulu. Yeh Pulu is a small hermitage dating back to the 14th century. Although being very close to the famous Goa Gajah, this site receives only a few tourists. A short walk from the ticket office through rice-fields 
leads to a unique frieze carved into a cliff face. It is of two-metre high and 25-meter in length. The relief depicts everyday life in Bali with various figures walking, playing with animals, and hunting scenes. Compared to other Balinese carvings, figures of Yeh Pulu frieze are much more natural and vivid.
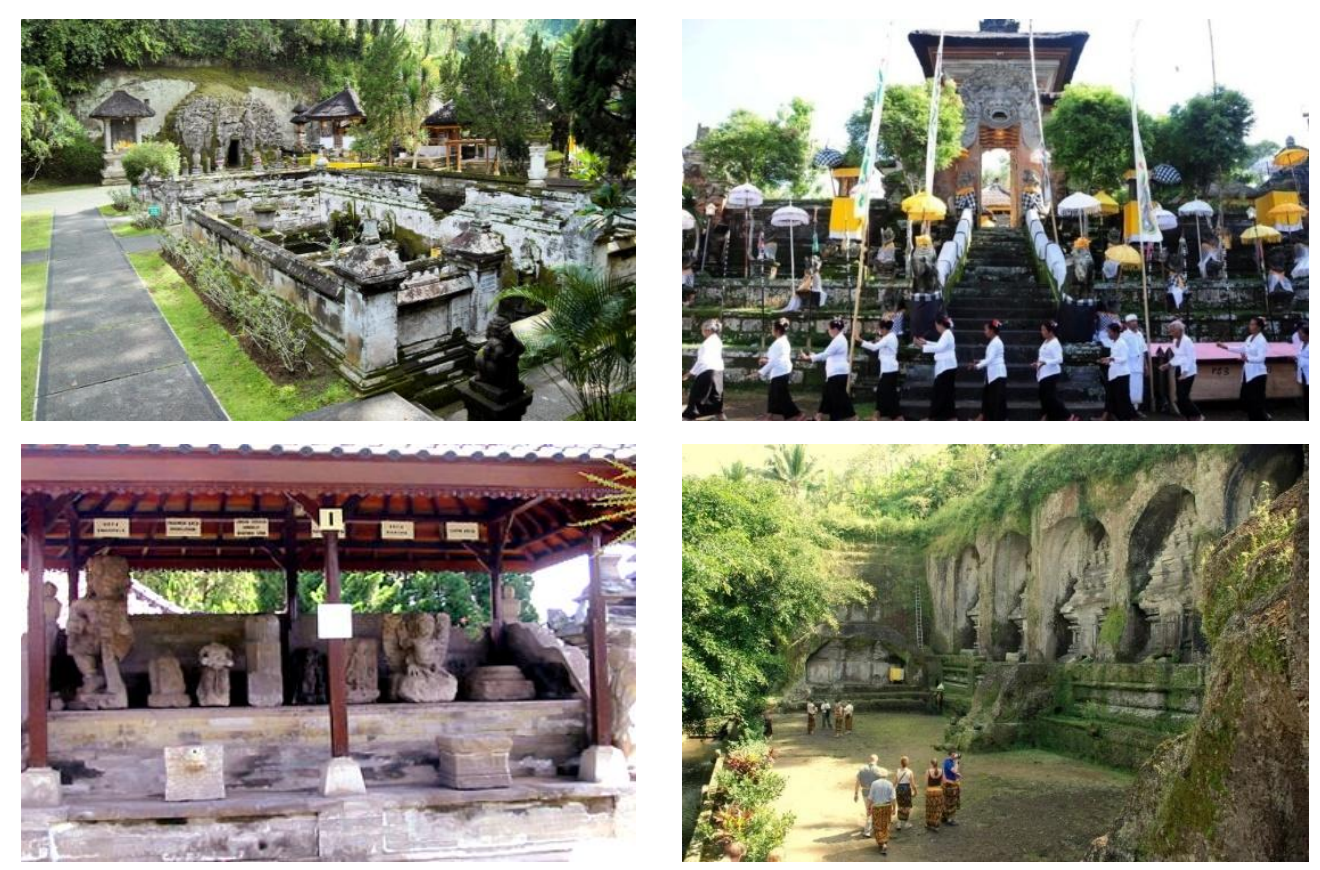

Figure 1. Goa Gajah, Samuan Tiga Temple, Gedong Arca Purbakala, and Yeh Pulu.

\section{Activities}

One type of tourist activity offered in Bedulu is educational tourism, such as cooking, cultural, or language classes. These activities are presented in the form of package tour with variable fee. The cooking class taught tourist to cook Balinese specialty and Indonesian food. Other similar classes include cultural and language classes, which teach Balinese language, dance, gamelan, or making handicrafts. These activities involved the villagers with a key role in either the participation, teaching, or providing accommodation. Some of these activities are as follows:

Cooking class. This class taught tourists to make traditional Balinese food, such as Bebek Betutu, Sate Lilit, Lawar, and Sambel Matah. This activity is carried out in order to preserve and introduce the Balinese culinary to foreign and domestic tourists. For foreign tourists, the activity includes selecting ingredients on traditional market and cooking with instruction from the guide until the food is ready to serve and to be enjoyed together at dinner. It is arranged so that the tourists can immediately interact with the public market in order to create memorable and unique experiences. There are two schedules for cooking class: morning class starts from 08.30 and afternoon class starts from 15.30, in order to provide tourist with time flexibility.

Cultural and language class. Cultural attractions include: mejejahitan, nanding canang, mebanten, egg and canvas painting, making traditional Balinese snack (sumping, banttal, and laklak), grilling satay, making satay skewers, making ceremonial accesories, such as kelakat, kelangsah, and sengkui, making sculptures out of wood, and mebongbong chicken. There are also dance and Balinese languange classes for those interested. These classes are open for public, and generally take about 60-90 minutes per day, although some package offer up to one week of continuous classes. 
Entertainment. Entertainment attractions are displayed at dinner, with the dance performance of Studio Subadrika of Puri Bedulu. Dance shown is as follows: Panyembrama dance, Legong Kraton, Oleg Tamulilingan, Baris Dance, Joged, and Kecak (on request).
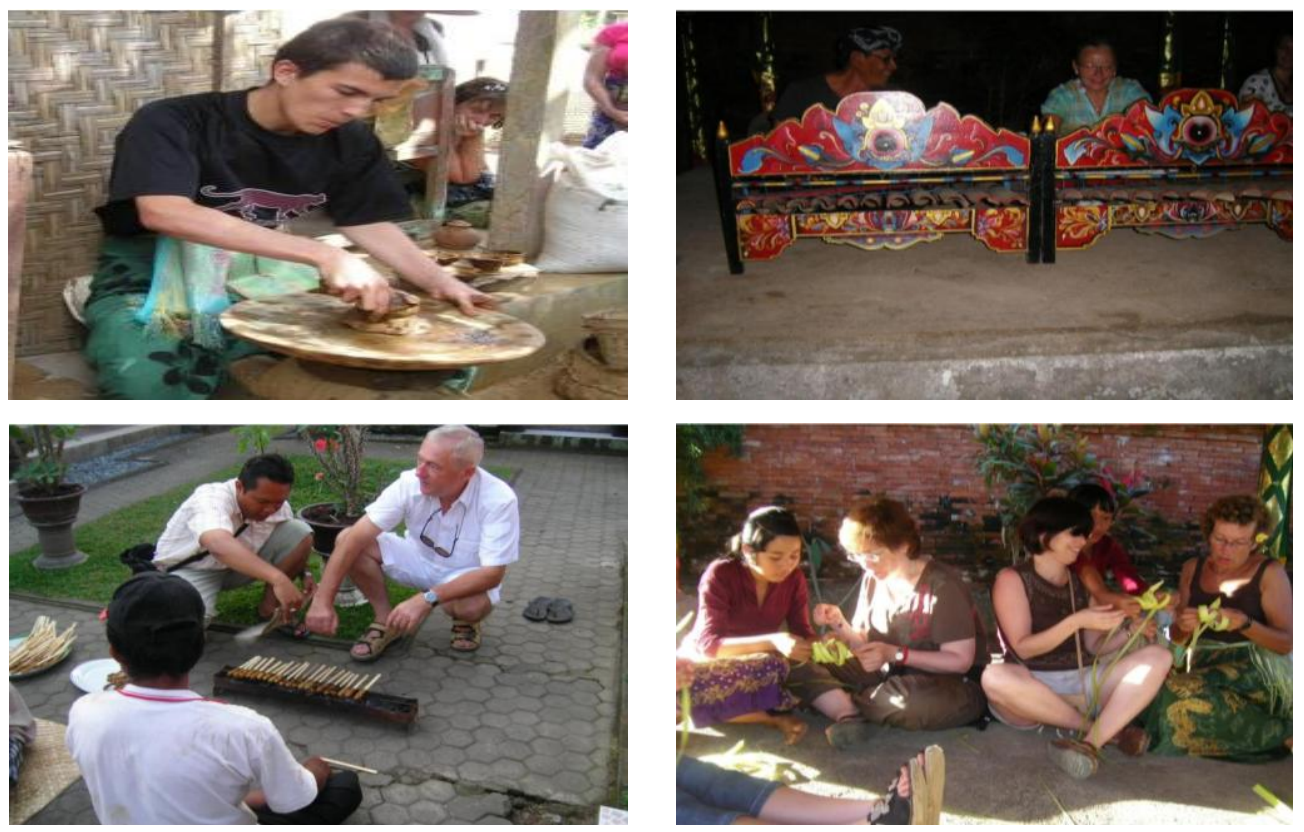

Figure 2. Tourist activities in Bedulu.

\section{Amenities}

Bedulu Village provides several accommodations, such as lodgings and villas with various rents. Also, several restaurants located close to tourist attractions, such as Goa Gajah are available. There are at least 20 local houses converted into homestay for tourist, along with conventional inns, villa, and hotels, such as Alami Villa, Bali Kulkul Guest House, Chedi Club Tanah Gajajh, Ubud Dedari Villas, and Puri Alam Dewata. The price range is between Rp.200,000-1,000,000 per night, depends on the type of accomodation and facilities. Restaurants, such as Bale Udang and Jangggar Ulam near Goa Gajah provides seafood, while others also serve Balinese and Indonesian menu. There are also other amenities available, such as supermarkets, money changers, travel agencies, tourist information centers, and public toilets around the tourist areas.

\section{Accessibility}

According to French (1996, p. 204), the important factors for accessibility of tourist destinations are: “...road signage, access to tourist attractions, regional airport, and ground transport, ...time taken to rech the destination, the cost of traveling to the destintion, and the frequency of transport to the destination".

Bedulu Village is located between strategic tourist tracks "Ubud-Tampaksiring-Penelokan-Trunyan" and has a main street accessible by using various types of vehicles, such as buses, cars, and motorbikes, thus makes it easier for travelers who want to come to visit. The street pattern is still showing traditional style, there are some crossroads near the north-eastern area of Puri Bedulu. The houses are connected by a small road/path that serves as a means to facilitate the mobility of people and maintain smooth traffic of the village.

\section{Ancillary Sevices}

According to Reynish et al. (2009, p. 69), ancillary services are secondary services which support amenities 
and are facilities that are vital for the successful operation of all tourism businesses. Ancillary services are important in order to create a tourist destination because every destination needs to have extra services which will benefit tourists to enhance their experience. Tourism in Bedulu Village is managed by "Dharmodayana Foundation" founded by Drs. A. A. Gede Rai Oka Astawa, M. Hum., which manages tourist attractions, accommodations, and activities. In addition, the village has collaborated with several travel agencies, both local and abroad, such as Golden Kris Tour and the Asian World.

\section{Discussion}

The prospect of Bedulu as tourism village was first considered by A. A. Gede Rai Oka Astawa of Dharmodayana Foundation alongside Ketut John. They proposed the idea to Bali Tourism Board in 2007. The proposal was accepted in 2011 and the foundation was given funds of 150 million rupiah. With these funds, the Darmodayana Foundation began to plan and execute programs for tourism village. Starting with public dissemination, involving the community in providing accommodation and giving assistance to travellers in conducting cultural activities, local people who joined in Kecak Bedulu and local dance studio also invited and involved in the activities of this tourist village. Since it opened and developed, this tourist village evolved positively. The number of tourists who visit Bedulu in 2012 was 525 and in 2011 as many as 400 tourists with an average length of stay of two nights. According to 2015 census, about $30 \%$ locals are craftsmen, which is the result of growing tourism in Bedulu, and $19.1 \%$ in service industry, which includes tour guides, sellers in art shops, and restaurants. These mean that tourism has involved decent amount of local community and help provides jobs in the village.

Table 1

Profession in Bedulu (2015)

\begin{tabular}{llll}
\hline No. & Profession & Amount & Percentage $(\%)$ \\
\hline 1 & Student & 2,745 & 28.6 \\
2 & Farmer & 2,142 & 22.3 \\
3 & Craftsmen & 2,881 & 30 \\
4 & Service & 1,836 & 19.1 \\
Total & & 9,604 & 100 \\
\hline
\end{tabular}

Bedulu Village offers educational and cultural tourism as a package tour program. The visitors may participate in various activities of Balinese culture. The types of activities offered, for instance, the art of pottery, sculpture, eggs and canvas painting, mejejahitan, dance and tabuh, learning Balinese language, as well as cooking class. All activities aimed to introduce Balinese culture to tourists, which gave the impression as an authentic tourist experience. These activities are managed by the village foundation, in which the villagers acted as instructors or demonstrators, alongside tour guides to help explain things to the tourists. This shows that the tourism activities in Bedulu Village are a community-based tourism, where local residents of a tourism destination play an active role in various types of tourism activities in the area.

Community is expected to participate in tourism activities. The purpose of community-based tourism is to verify whether individual, organization, and community has built their ability to anticipate tourism development in their area where their community are living. Tourism development will not be successful without community leader and all communities are involved. As one example case study in Shiraz, Iran, the place has good prospect for tourism development, however, without community participation, tourism industry in Shiraz is not possible to 
increase (Aref dan Ma'rof, 2008). However, similar to the findings by Putra (2009), on his research in Gianyar District, this paper also found that Bedulu Village still has some obstacles on the development, such as the lack of human resources both in quality and number. For examples, French-speaking guides are still scarce, while there are a lot of French tourists visiting. The management tried to get around this by cooperating with several travel agents to provide the guides. Therefore, one of the challenges on development of Bedulu Village is empowerment for local residents in order to provide quality human resources, in addition to accommodation and road maintenance. A lot of local communities realize the importance of tourism in stimulating social change, culture, environment, and economic dimension, where tourism activities have had close relationship with local people (Beeton, 2006). Tourism is just like a tool that used by community to promote economic development. In conjunction with the issue, community leaders in the area of development are playing an important role in taking care of tourism problem. Meanwhile, tourism development and community empowerment are the recipe for community welfare, as stated by Godfrey dan Clarke (2000) towards local community. Empowerment concept arises as an effort to give local community or marginal people to quit from voicelessness and powerlessness condition. According to World Bank (2002), basically, empowerment has four main elements, i.e.:

1. Access to information, because information is capital in dependence development. Community who has sufficient information will have better position in using the opportunity, easier to get service access, using their rights, also asking for responsibility of the stake holders.

2. Inclusion/participation, chance to participate in tourism development, either is planning, implementation, or result use are very important to local community. With those participation, all decisions are based on local knowledge), local wisdom, as well as the priorities are match with local community aspirations, it will be ended to local community commitment in development process including tourism development.

3. Accountability. Accountability of all stakeholders is needed, including in developing the role, implementation, or any kind of resources usage including funds. Accountability must be done in order to get community trust; in the other side, communities are also educated to develop their accountability amongst them, with other parties vertically, horizontally, and internal accountability (vertical, horizontal, and internal accountability).

4. Local organizational capacity. Community empowerment process must consist of quality ability development, ability to work in a team, develop and strengthen local organization, as well as mobilization resources to anticipate any problems. Community will be able to speak out their need and aspiration in a group than individually.

Development of village tourism is one of best sample in community-based development, with main empowerment component being empowerment of local community in the area of development. This model is inline with four-tracks strategy that is programmed by President Susilo Bambang Yudhoyono, especially in components of pro-poor, pro-job, pro-growth, and pro-environment (Tempo. co, 2009).

\section{Conclusions}

Results of the study show the potential of Bedulu Village as a tourist attraction is quite large in both natural and socio-cultural. Bedulu Village is an ancient village, so there are a lot of cultural and archaeological heritages which act as tourist attraction. Travelers can enjoy pilgrimage, culture, education, and nature tourism alongside tour guide services. There are also various types of accommodation and restaurants available across the village. Bedulu Village provides about 20 local houses as homestay, as well as several inns and villas. Supermarkets, 
souvenir shops, money changers, and tourist information centers are easy to find around the tourist area, but this paper found the conditions of these accommodation still lacks in cleanliness and also not properly maintained. The main road is wide and well-maintained which made it easier to reach tourist attractions. But the road to the inn (home stay) is fairly narrow and uncomfortable, only accessible by one four-wheel vehicle at a time. The road to some atractions, such as Yeh Pulu is also narrow and a little damaged. This may give a negative impression because the narrow road will limit the number of vehicles entering as well as the number of visiting tourists. Despite these shortcomings, overall Bedulu Village has been adequately prepared in terms of tourist attractions and tourist accommodation. For future tourism, Bedulu Village still in need of further development in areas, such as infrastructure, marketing, and the empowerment of local community. The management, development, and financing of tourism area require involvement and support of many stakeholders (public, private, and society) in order to ensure that the process will run smoothly. This will allow the village to stay competitive in the face of mass tourism of nearby places, like Ubud and lead to community's welfare, which in turn will secure future tourism of Bedulu Village.

\section{References}

Adiprana, I. P. G., \& Mahagangga, I. (2013). Dinamika Perkembangan Pariwisata di Desa Pakraman Ubud. Jurnal Destinasi Pariwisata, 1(1), 34-43.

Antara Bali. (2010, December) Gianyar Usulkan 9 Desa Wisata ke Menbudpar. Retrieved from http://www.antarabali.com/berita/8697/gianyar-usulkan-9-desa-wisata-ke-menbudpar

Aref, F. \& Ma'rof, R. (2008). Barriers to Community Participation Toward Tourism Development in Shiraz, Iran. Pakistan Journal of Social Sciences, 5(9), 936-940.

Ardika, I. G. (2011). Wisata Desa, Konsep dan Pengembangannya. Proceedings of Seminar Implementasi DMO Labuanbajo, 21-23 September.

Beeton, S. (2006). Community development through tourism. Landlinks Press.

Christou, E. (2005). Heritage and cultural tourism: a marketing-focused approach. Teoksessa International Cultural Tourism: management, implications and cases, 3-15.

Dharmodayana Foundation. (2011). Pengembangan Desa Wisata Bedulu (DEWI Bedulu). Gianyar, Bedulu: Astawa, AAG.Oka.

Disparda Bali. (2017, April). The number of foreign tourists arrival to Bali by month 2008-2017. Retrieved from http://www.disparda.baliprov.go.id/files/subdomain/disparda/2.\%20DISTRIBUSI\%20jan\%202017.xls

French, T. (1996). World airport development plans and constraints. Travel \& Tourism Analyst, (1), 4-16.

Godfrey, K., \& Clarke, J. (2000). The tourism development handbook: a practical approach to planning and marketing. Burns \& Oates.

Nuryanti, W. (1993). Desa Wisata Dan Lingkungannya. Jakarta: Gramedia.

Putra, A. M. (2009). Pengembangan Daya Tarik Wisata Jatiluwih Berbasis Tri Hita Karana di Kabupaten Tabanan (Unpublished Master's Thesis, Udayana University, Denpasar).

Reynish, N., Ivanovic, M., Khunou, P. S., Pawson, R., Tseane, L., \& Wassung, N. (2009). Tourism development 1: Fresh perspectives. Cape Town: Pearson Education and Prentice Hall.

Safitri, Y. A., \& Sukana, M. (2013). Partisipasi Masyarakat Lokal dalam Kegiatan Kepariwisataan di Desa Jatiluwih Kabupaten Tabanan. Jurnal Destinasi Pariwisata, 1(1), 44-53.

Sigala, M. and Leslie, D. (2005). International cultural tourism: Management, implications and cases. Routledge.

Suarthana, I. K. P. (2015). Dampak Partisipasi Masyarakat dalam Pengelolaan Desa Wisata terhadap Sosial Budaya, Lingkungan, dan Ekonomi: Kajian Komparatif Antara Desa Wisata Bedulu, Bali dan Pentingsari, Yogyakarta (Doctoral dissertation, Udayana University). Retrieved from http://erepo.unud.ac.id/id/eprint/10139

Suarthana, I. K. P., Agustini, L. P., \& Hardini, W. (2015). The impact of social, economic and environment in local community participation of archeological tourism village Bedulu Gianyar, Bali. Journal of Business on Hospitality and Tourism, 1(1), $1-12$. 
Sutawa, G. K. (2012). Issues on Bali tourism development and community empowerment to support sustainable tourism development. Procedia Economics and Finance, 4, 413-422.

Tempo. co. (2009, August). RAPBN 2010: Pro Growth, Pro Poor, Pro Job. Retrieved from https://nasional.tempo.co/read/190398/rapbn-2010-pro-growth-pro-poor-pro-job/full\&view=ok

The World Bank (2002). The MDGs as a Benchmark for Development Effectiveness. Retrieved from http://siteresources.worldbank.org/ IDA/Resources/ ARDE_2002.pdf

The World Bank (2016). October 2016 Indonesia Economic Quarterly: Pressures Easing. Retrieved from http://www.worldbank.org/en/country/indonesia/publication/indonesia-economic-quarterly-october-2016 